\title{
Lower/Middle Ordovician (Arenigian) shallow-marine trace fossils of the Pochico Formation, southern Spain: palaeoenvironmental and palaeogeographic implications at the Gondwanan and peri-Gondwanan realm
}

\author{
F.J. Rodríguez-Tovar ${ }^{1}$, M. Stachacz², A. Uchman², M. Reolid ${ }^{3}$ \\ ${ }^{1}$ Departamento de Estratigrafia y Paleontología, Facultad de Ciencias, Universidad de Granada, 18002 Granada, Spain \\ ${ }^{2}$ Jagiellonian University, Institute of Geological Sciences, Oleandry Str. 2a, PL-30-063 Kraków, Poland \\ ${ }^{3}$ Departamento de Geología, Universidad de Jaén, Campus Las Lagunillas sn, 23071 Jaén, Spain
}

e-mail addresses: fjrtovar@ugr.es (F.J.R.-T., correspondingauthor); michal.stachacz@uj.edu.pl (M.S.),alfred.uchman@uj.edu.pl (A.U.); mreolid@ujaen.es (M.R.)

Received: 29 January 2014 / Accepted: 13 August 2014 / Available online: 30 October 2014

\begin{abstract}
Nineteen ichnospecies belonging to thirteen ichnogenera (Archaeonassa, Catenichnus, Cochlichnus, Cruziana, Didymaulichnus, ?Diplichnites, Gordia, Lingulichnus, Lockeia, cf. Monocraterion, Planolites, Ptychoplasma, and Rusophycus) occur in the Pochico Formation (Arenigian) in the Aldeaquemada section, Sierra Morena, southern Spain, just above the Armorican Quartzite. They belong to the archetypal Cruziana ichnofacies, indicating a lower shoreface-upper offshore zone. The low degree of sediment reworking may be due to a high rate of sedimentation. The trace fossil assemblage, rich in large Cruziana, is typical of the Armorican Quartzite that developed on the margins of Gondwana and peri-Gondwanan microcontinents. The distribution of ichnofauna during the Early Ordovician was partly palaeogeographically controlled, although ichnological data from the literature point to paths of migration between Gondwana, Baltica and Laurentia. Differences between the ichnofauna of Gondwana and Baltica could be conditioned by facies (clastics in Gondwana and carbonates in Baltica) causing a taphonomic filter, because Cruziana requires diversified clastic deposits for preservation. The ichnofauna would also be influenced by trophic group amensalism between filter feeding and deposit feeding fauna, the former prevailing in Baltica and the latter in Gondwana.
\end{abstract}

Keywords: Ichnofossils, Arenigian, clastic sediments, Gondwana, peri-Gondwana, Iberia

Resumen

Se presenta el análisis sedimentológico/icnológico de los materiales de la Formación Pochico (Arenigian) de la sección de Aldeaquemada, Sierra Morena, Sur de España, provincia de Jaén, justo por encima la Cuarcita Armoricana. Se han reconocido diecinueve icnoespecies pertenecientes a trece icnogéneros (Archaeonassa, Catenichnus, Cochlichnus, Cruziana, Didymaulichnus, ?Diplichnites, Gordia, Lingulichnus, Lockeia, cf. Monocraterion, Planolites, Ptychoplasma, y Rusophycus). Las características icnológicas junto con los rasgos sedimentológicos permiten asignarlas a las icnofacies arquetípicas de Cruziana, comunes de las zonas de shoreface inferior a offshore superior. El grado de bioturbación relativamente bajo puede estar relacionado con una alta tasa de depósito. La asociación registrada, dominada por grandes Cruziana, es típica de la Cuarcita Armoricana desarrollada en los márgenes de Gondwana y peri-Gondwana. La distribucción de icnofósiles del Ordovícico temprano posee, en gran medida, un control paleogeográfico, aunque datos icnológicos procedentes de la literatura indican la existencia de migraciones entre Gondwana, Baltica y Laurentia. Las diferencias entre las asociaciones de Gondwana y Báltica pueden estar asociadas a las diferentes facies, con el dominio de materiales clásticos en Gondwana y de carbonatados en Báltica, causando un filtro tafonómico ya que el potencial de conservación de Cruziana es mucho mayor en las facies clásticas heterolíticas. A estos factores habría que añadir las estrategias de alimentación asociadas, diferenciando entre filtradores y aquellos que se alimentan de las partículas existentes en el sedimento, los primeros podrían verse favorecidos en Báltica y los segundos en Gondwana. 


\section{Introduction}

Arenigian shallow-marine clastic sediments of Western Europe, North Africa, South America and some parts of North America are characterized by abundant trace fossils, including large Cruziana, an ichnogenus first described from such deposits in Bolivia (d'Orbigny, 1842). Trace fossils of these facies are largely associated with quartzitic sandstones, in France and on the Iberian Peninsula largely attributed to the Armorican Quartzite (Grès Armoricain) (Gutiérrez-Marco et al., 2002). The Armorican Quartzite, dated mostly to Arenigian, was deposited in several disconnected basins supplied from local sources (Torsvik and Cocks, 2011). The Armorican Quartzite and associated deposits rich in quartzite sandstones may be considered as a facies deposited in shallow seas in the margin part of Gondwana and peri-Gondwanan microcontinents in the stage of rifting and early drift of Avalonia (Gutiérrez-Alonso et al., 2007). This area was a southernmost part of Gondwana and was situated near the South Pole during the Early Ordovician (e.g., Cocks and Torsvik, 2002).

Although a general ichnological characterization of the Armorican Quartzite is lacking to date, trace fossils are an important feature of this facies. They have been described in several sections and areas on the Iberian Peninsula (e.g., Delgado, 1886a, b; Bouyx, 1966; Baldwin, 1975, 1977a, b, c; Crimes and Marcos, 1976; Kolb and Wolf, 1979; Pickerill et al., 1984; Romano, 1991; Neto de Carvalho, 2006; Sá et al., 2011 ) and in France (Rouault, 1850; Lebesconte, 1883, 1886; Durand 1984, 1985a, b; Fortey and Owens, 1999).

In this paper, we describe a trace fossil assemblage in one section of the Armorican Quartzite facies, just on the transition of the Armorican Quartzite sensu stricto, and overlying heterolithic facies of the Pochico Formation in the Aldeaquemada section (Cimbarra section in Rey and Hidalgo, 2004), Central Iberian Zone (Fig. 1). Its palaeoenvironment is interpreted in the Gondwanan and peri-Gondwanan context. Considering that the Pochico Formation is ichnologically almost unexplored, a discussion of the more general ichnological features of this facies based on the literature serves to support our interpretation. Collected trace fossils are housed in the Department of Stratigraphy and Palaeontology, Faculty of Sciences, University of Granada (label Aq).

\section{Geological setting}

During the Early Ordovician, the Iberian Massif formed part of the northwest margin of Gondwana (e.g., Von Raumer et al., 2003). The studied area is located in the southernmost part of the Iberian Massif, in the Central Iberian Zone, according to a subdivision into different zones (Fig. 1A) based on different stratigraphic-tectonic-metamorphic features (Julivert et al., 1972). The studied outcrop is located in the Cascada de la Cimbarra, in the Sierra Morena Mountains (Fig. 1B), province of Jaen, $2.5 \mathrm{~km}$ south of Aldeaquemada village by the El Negrillo pool of the Guarrizas River (GPS co-ordinates: $\mathrm{N} 38^{\circ} 23.150^{\prime} ; \mathrm{W} 003^{\circ} 22.474^{\prime} ; \pm 9 \mathrm{~m}$ ). Additional material was observed in the surroundings, especially at the bottom of the valley near this site, where nearly horizontal beds offered other in situ occurrences (GPS co-ordinates: $\mathrm{N} 38^{\circ} 23.136^{\prime}$; W0032․ $2332^{\prime} ; \pm 8 \mathrm{~m}$ ). Both localities are within the Despeñaperros Natural Park.

The Lower/Middle Ordovician in the Aldeaquemada area comprises two lithostratigraphic units: the Armorican Quartzite Formation and the Pochico Formation (Fig. 1C). The Armorican Quartzite in the Central Iberian Zone is up to $500 \mathrm{~m}$ thick and composed of white orthoquartzites. The lower part of the Armorican Quartzite Formation is not outcropping in the studied area, but its upper member, about 200 $\mathrm{m}$ thick, with beds ranging from $30 \mathrm{~cm}$ to $12 \mathrm{~m}$, is identified in the Aldeaquemada area and described by Rey and Hidalgo (2004) and Lillo et al. (in press). Top beds of this member display wavy bedding, cross-stratification and the trace fossil Cruziana.

The Pochico Formation, around 200 m-thick in the studied area, is made up of alternating quartzites, quartz sandstones, sandy shales, siltstones and mudstones. Stratal stacking allows three members to be distinguished (Tamain, 1972). According to Gutiérrez-Marco et al. (2013), the Pochico Formation probably corresponds to the Dapingian sequence sensu lato in the southern part of the Central-Iberian Zone in Spain, being in this case the Middle Ordovician in age (Bergström et al., 2009). The Lower Member (Pochico Alternations Member) is around $60 \mathrm{~m}$ thick and features a series of quartzite beds alternating with finer sediments, showing wavy-bedding (Fig. 2A), horizontal lamination (Fig. 2D), wave ripple cross-lamination and locally low angle cross-stratification (Fig. 2E). The Middle Member (Yellowish Pochico Sandstone Member) contains about $100 \mathrm{~m}$ thick sandy shales with wavy-bedding and locally hummocky cross-stratification. A few horizons show distinct cracks (Fig. 2F). In the Middle Member, lingulid horizons have been recorded and related to short catastrophic events (Emig and Gutiérrez-Marco, 1997). The Upper Member or Pochico Quartzite Intercalations Member (50 m thick) is characterized by numerous quartzite beds intercalated with finer clastics, similar to the first member. Most of these rocks are characterized by the low degree of sediment reworking and primary structures are usually clearly visible.

This study is focused on sedimentological and ichnological features at the transition between the Armorican Quartzite Formation and the Pochico Formation, where a 29 m-thick section was measured bed by bed (Fig. 3). These formations contact with a conformity showing gradual lithological transition. According to Matas-González et al. (2009), the Lower Member of the Pochico Formation was deposited on a siliciclastic shelf dominated by storms.

Trace fossils were rarely mentioned from the Armorican Quartzite and the Pochico Formation (especially the lower 
Fig. 1.- Geological setting. A, Iberian Peninsula and subdivisions of the Iberian Massif according to stratigraphic, tectonic and metamorphic features. The studied area is located in the southernmost part of the Central Iberian Zone. B, Detailed geological setting of the studied outcrop (GPS co-ordinates: $\mathrm{N} 38^{\circ} 23.150^{\prime} ; \mathrm{W}^{\prime} 03^{\circ} 22.474^{\prime} ; \pm 9$ m). C, Aldeaquemada section and illustrations of the lithological formations appearance in the field. Note location of the studied profile as a bar.
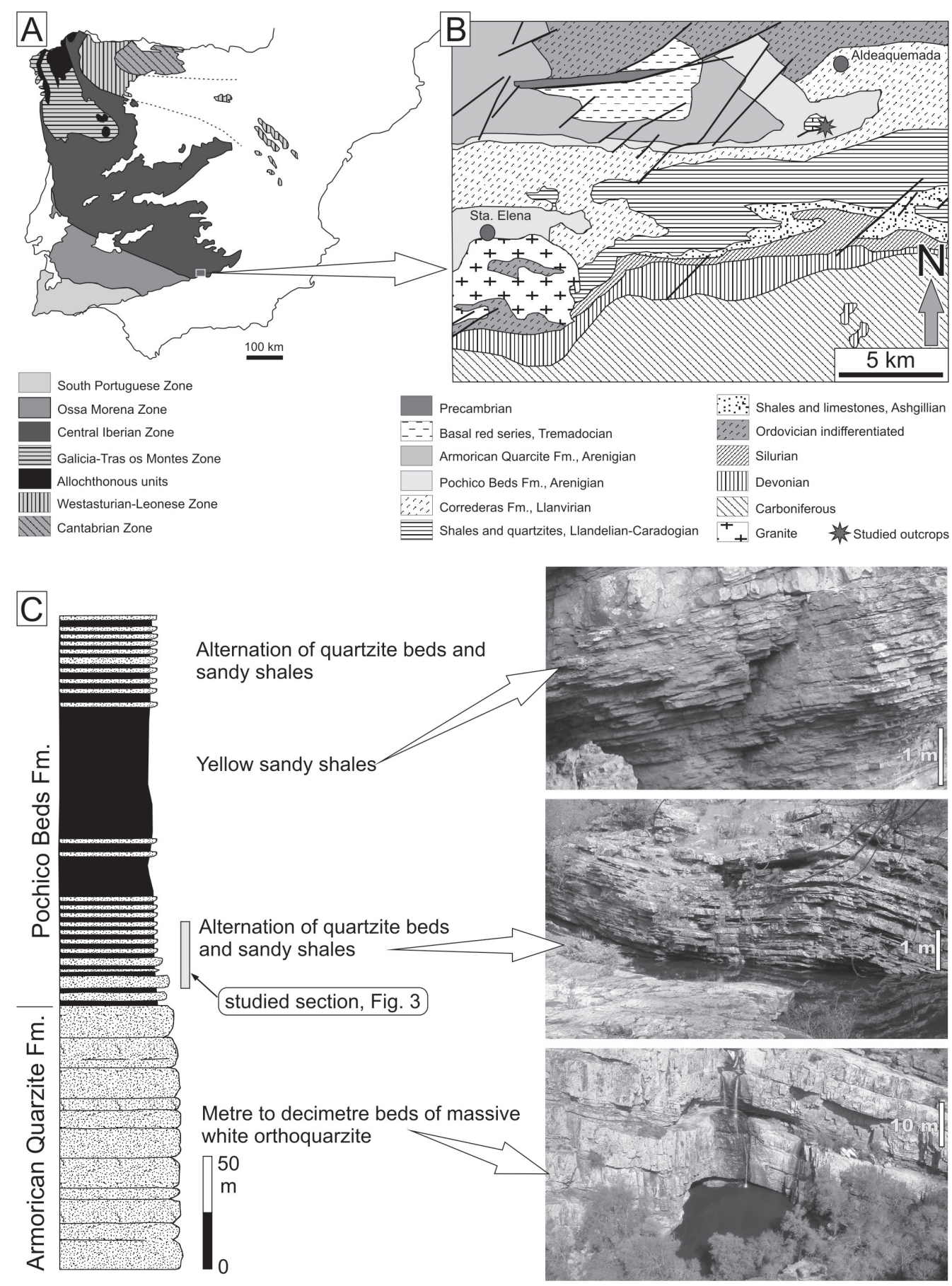

member) of the study area, which is covered by the Geological Map of Aldeaquemada (862, 1:50,000; a second edition still in press is unavailable, see Lillo et al., in press). Rey and Hidalgo (2004) mention large and small Cruziana and Skolithos from the lower part of the Pochico Formation in the study region. In the surrounding areas, trace fossils have been described in the Pochico Formation, including Cruziana furcifera, C. goldfussi, C. rugosa, Rusophycus isp., Didymaulichnus rouaulti, Arthrophycus cf. harlani and Daedalus halli (Pérez Regodón, 1966; Butenweg, 1968; Poupon, 1971; Tamain, 1972). In nearby areas, covered by the surrounding Geological Maps 838 (Santa Cruz de Mudela), 840 (Bienservida), and 787 (Alhambra), other ichnotaxa, such as Cruz- iana cf. lefevbrei, Didymaulichnus lyelli, Monocraterion isp., Monomorphichnus isp., Bergaueria isp. and Isopodichnus isp., are mentioned in the map explanations.

\section{Systematic palaeontology}

Ichnogenus Archaeonassa Fenton and Fenton, 1937a cf. Archaeonassa isp. (Fig. 4A)

Material: One loose slab in the field.

Description:

Epichnial, shallow furrow, 2-3 $\mathrm{mm}$ wide, with narrow levees. Its course is slightly to strongly winding with occasional loops. The loops measure 15-30 mm across. 

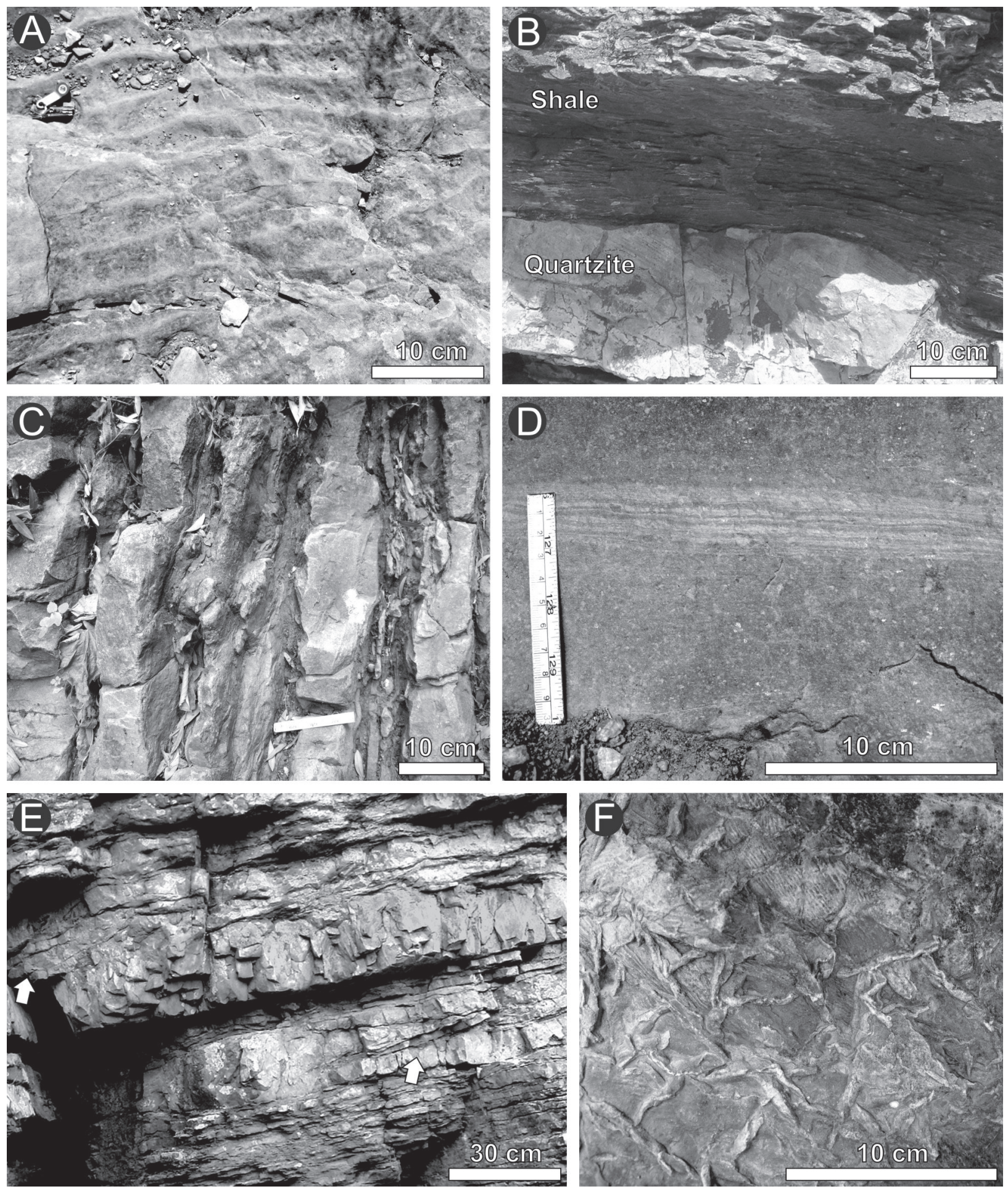

Fig. 2.- Sedimentary structures from the Aldeaquemada section. A, Wavy ripples on the top of beds of quartzite. B-C, Heterolithic quartzite-siltstone deposit. D, Beds of quartzite with parallel lamination. E, Low angle cross-stratification in sandstone beds. F, Cracks in upper surface of beds.

\section{Remarks:}

The winding course with occasional loops resembles Helminthoidichnites Fitch (Hofmann and Patel, 1989), which however does not display levees, when preserved as a furrow. Levees are typical of Archaeonassa fossulata Fenton and Fenton, 1937a, the type ichnospecies of Archaeonassa, which is interpreted as a crawling trail of gastropods (Fen- ton and Fenton, 1937a; Buckman, 1994; Stanley and Feldmann, 1998) or crustaceans (Yochelson and Fedonkin, 1997; Mángano and Buatois, 2003). A. fossulata is larger and does not display loops as the described cf. Archaeonassa isp.

Ichnogenus Catenichnus McCarthy, 1979

Catenichnus isp. (Fig. 4B) 
Material: About 10 specimens in the upper part of a quartzitic sandstone bed observed in the field.

\section{Description:}

U-shaped cylinder with divergent arms. The cylinder is of uniform diameter, which ranges from 7 to $11 \mathrm{~mm}$ among specimens. The structure is $11-60 \mathrm{~mm}$ wide and approximate- ly $20 \mathrm{~mm}$ deep. The cylinders are thinly to thickly lined with mudstone or siltstone.

\section{Remarks:}

Some of specimens of the type ichnospecies Catenichnus contentus McCarthy, 1979 from the Permian of Australia, display poorly developed spreite, which are absent in the studied

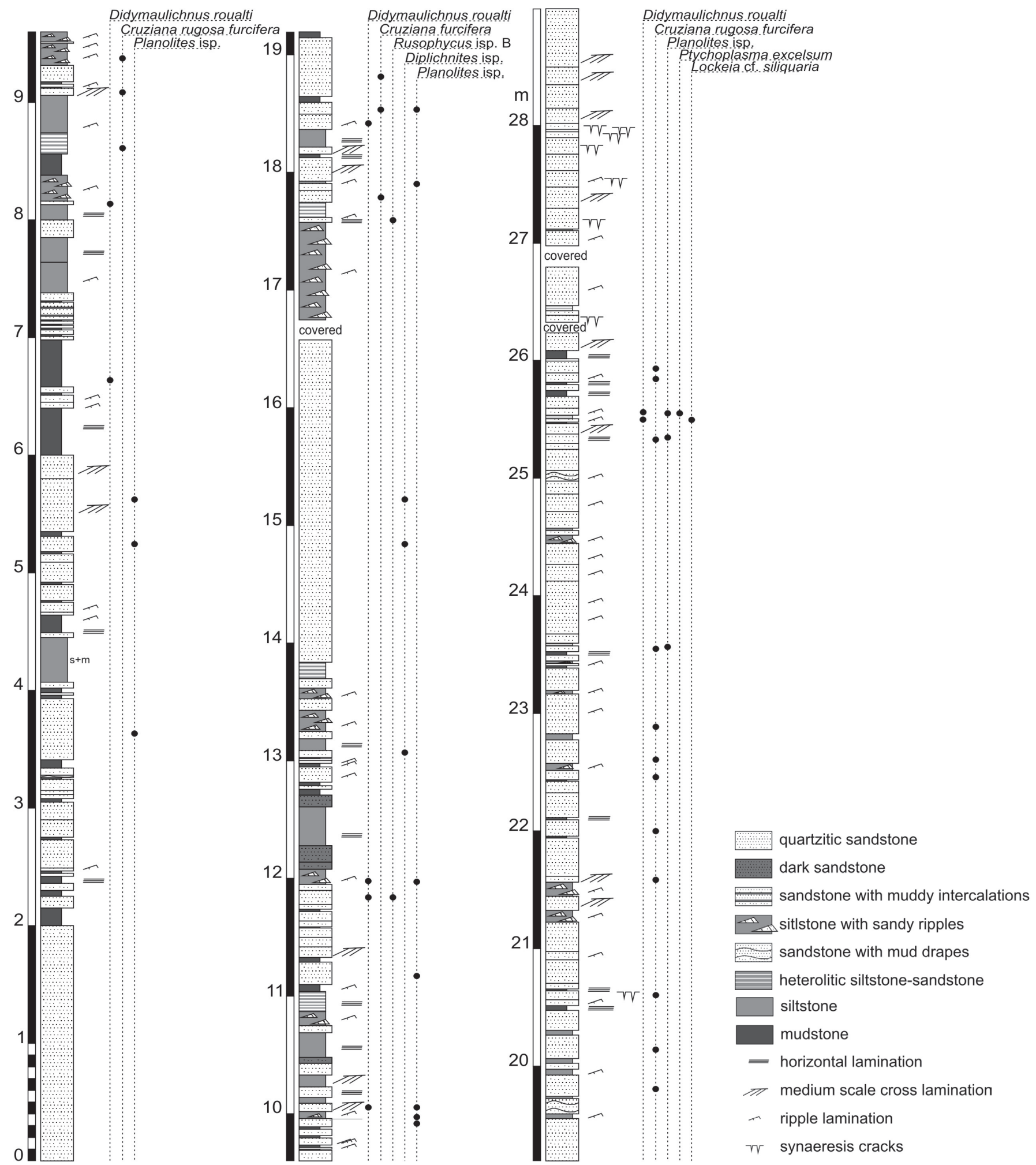

Fig. 3.- Profile of the Cascada de la Cimbarra outcrop with indication of sedimentary structures and ranges of selected trace fossils. 
material. Trace fossils of this morphology, but without spreite, are also ascribed to Arenicolites, which however displays parallel arms (see Hofmann et al. 2011 for discussion). Catenichnus contentus can be interpreted as a domichnion produced by a suspension feeder (McCarthy, 1979). It occurs in moderate to high energy facies (Fillion and Pickerill, 1990). The same interpretation may be applied to Catenichnus isp. described here.

Ichnogenus Cochlichnus Hitchcock, 1858

Cochlichnus isp. (Fig. 7D)

Material: Two specimens observed in the field.

Description:

An epichnial, horizontal, regularly sinuous ridge. The ridge is $2 \mathrm{~mm}$ wide. The amplitude of the meanders attains $6-8 \mathrm{~mm}$ and the meanders are $2 \mathrm{~mm}$ high.

\section{Remarks:}

Cochlichnus occurs in a great variety of marine and nonmarine environments. It is produced by many different invertebrates, including annelids and nematodes (see Fillion and Pickerill, 1990, for review). Cochlichnus from non-marine settings have been referred to scavengers or predators (Głuszek, 1995), an interpretation that can also be extended to occurrences in marine settings.
Ichnogenus Cruziana d'Orbigny, 1842

Cruziana furcifera d'Orbigny, 1842 (Fig. 5A-F)

Material: Six specimens collected, with numerous occurrences observed in the field.

\section{Description:}

Straight to loosely meandering bilobate ridges of uniform width ranging from 30 to $130 \mathrm{~mm}$. The lobes of the ridges are semi-ellipsoidal in cross section and separated by a distinct $\mathrm{V}$-shaped furrow. Their surface is densely covered by oblique distinct ridges, which are $0.5-2 \mathrm{~mm}$ wide. The ridges meet in the median furrow at an angle less than $30^{\circ}$, forming a V-shaped unidirectional pattern. In some specimens, narrow lateral ridges are observed (Fig. 5C).

\section{Remarks:}

Delgado (1886) distinguished almost twenty ichnospecies of Cruziana from the Lower Palaeozoic of Portugal, yet Seilacher (1970) retained only C. furcifera, C. goldfussi and $C$. rugosa, and considered the remaining ichnospecies to be taphonomic variations of these three ichnospecies. The separation of Cruziana goldfussi (Rouault), distinguished from $C$. furcifera in terms of its finer and more continuous scratch marks (see Fillion and Pickerill, 1990 for discussion), is problematic because of transitional specimens. Also, the presence or absence of lateral ridges used to discern these two


Fig. 4.- A, cf. Archaeonassa isp., epichnial semirelief on medium bed of sandstone. B, Catenichnus isp. drawing on unfocused photograph of hyporelief on medium bed of sandstone. Cascada de la Cimbarra, Pochico Formation (Lower/Middle Ordovician). 

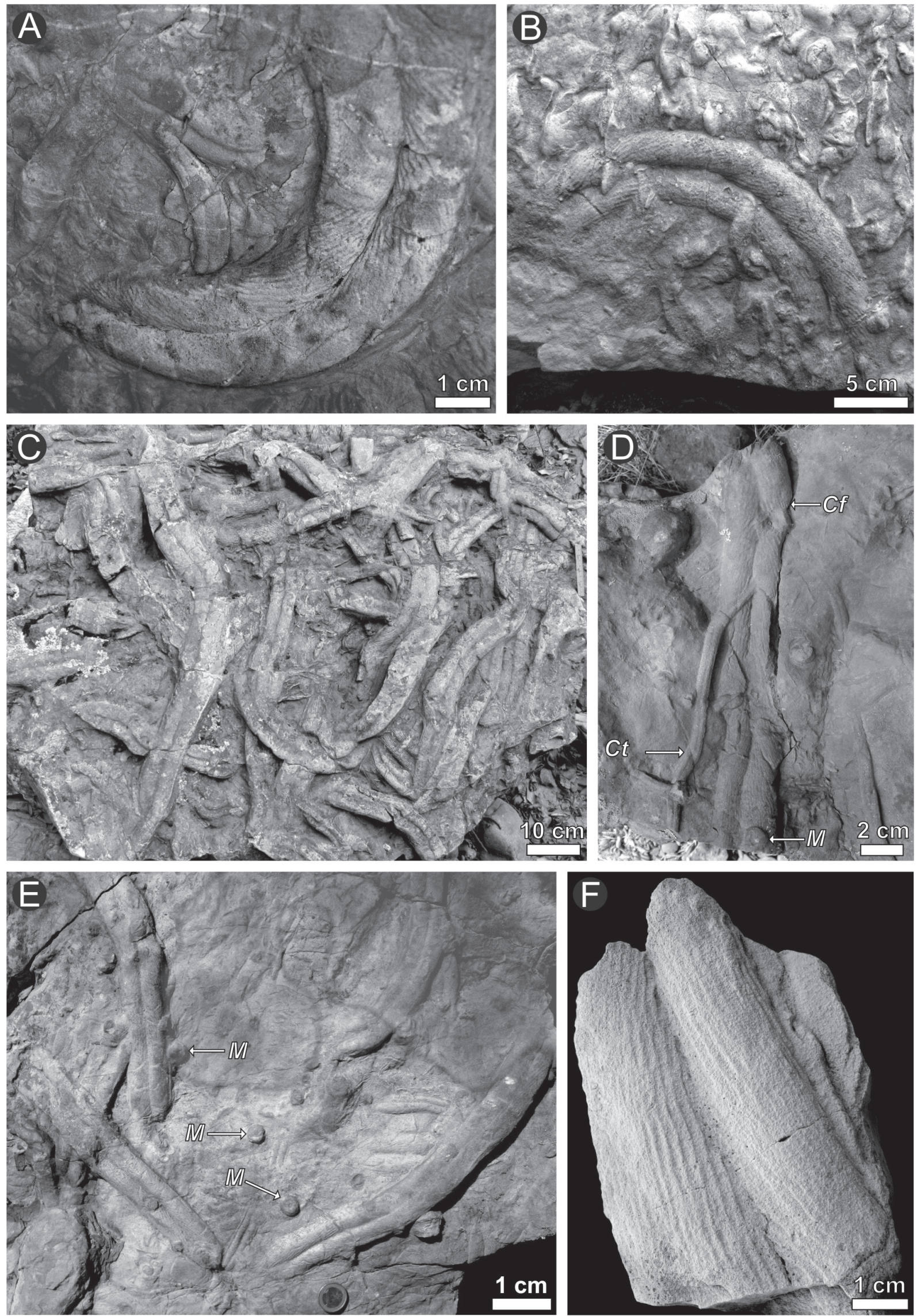

Fig. 5.- A-F, Cruziana furcifera d'Orbigny, 1842. Hypichnia with convex semirelief on medium to thick beds of sandstones. D, C. furcifera $(C f)$, C. tenella $(C t)$ and cf. Monocraterion isp. $(M)$. E, C. furcifera, cf. Monocraterion isp. (M). Cascada de la Cimbarra, Pochico Formation (Lower/Middle Ordovician). 
ichnotaxa, is problematic as they occur in the type material of both ichnospecies (Durand, 1985a). Therefore, Mángano and Buatois (2003) regarded C. furcifera, C. goldfussi and C. rugosa as subichnospecies of $C$. rugosa (respectively: $C$. rugosa furcifera, C. rugosa goldfussi and C. rugosa rugosa). However, many other authors retain them at the ichnospecies level (e.g., Aceñolaza and Milana, 2005; Neto de Carvalho, 2006) regarding that all the three ichnotaxa display distinctive morphological features (e.g., Egenhoff et al., 2007).

Cruziana is interpreted as the feeding trace of trilobites and/or other arthropods such as aglaspids, limulids or phyllopods, whereas C. rugosa is attributed exclusively to trilobites (e.g., Seilacher, 1970, 2007).

\section{Cruziana imbricata Seilacher, 1970 (Fig. 8A)}

Material: One slab containing two specimens.

Description:

A short, bilobate, hypichnial ridge, 8-20 mm long, 4-19 $\mathrm{mm}$ wide, 1-4 $\mathrm{mm}$ high. The lobes are covered by distinct, uniformly thick (1-2 mm wide), gently curved regularly distributed scale-like ridges, which meet in the median furrow at an angle of about $100^{\circ}$ and form a $\mathrm{V}$-shaped, unidirectional pattern in the median furrow.

Remarks:

The trace fossil was originally described as Cruziana imbricata Seilacher, 1970, which includes also forms that should be ascribed to Rusophycus (for the later see also Sá et al., 2011). Cruziana imbricata is common in the Arenigian in association the Cruziana rugosa group (Seilacher, 1970).

\section{Cruziana rouaulti Lebesconte, 1883 (Fig. 6C)}

Material: One collected specimen and a few specimens observed in the field.

\section{Description:}

This is a hypichnial bilobate ridge bounded with side ridges. The lobes are smooth, semi-circular in cross section, and show a wide median furrow. The whole structure is 11-18 $\mathrm{mm}$ wide. The side ridges are 1-3 $\mathrm{mm}$ wide.

\section{Remarks:}

This trace fossil was assigned to Didymaulichnus Young, 1972 (e.g., Crimes, 1970; Knaust, 2004), which mostly smooth, bilobate ridge. However, many authors ascribed it to Cruziana d'Orbigny (e.g., Neto de Carvalho, 2006; Seilacher, 2007). This is supported by the presence of scratches in well preserved specimens (Egenhoff et al., 2007). The strongly developed side ridges suggest a carapace of an arthropod. Crimes (1970) considered the discussed trace fossil as a trace of trilobites.

\section{Cruziana rugosa d'Orbigny, 1842 (Fig. 6A-B)}

Material: A few specimens documented in the field.

Description:

Hypichnial, bilobate ridge $90-100 \mathrm{~mm}$ wide, with transverse corrugations, covered by oblique, fine, comb-like ridges. The preserved fragments of ridges are 150-200 mm long.

\section{Remarks:}

The transverse corrugations are characteristic features of this subichnospecies. It is considered as a locomotion-feeding burrow of trilobites (e.g., Seilacher, 1970, 2007).

Specimen of Cruziana rugosa illustrated herein on Fig. 6 show only short fragment of up and down probing tracemaker work. Therefore, the resulted hypichnia (Fig. 6A) are similar to the rusophyciform of Rusophycus marginatus Bergström and Peel, 1988.

Cruziana tenella (Linnarsson, 1871) (Figs. 5D, 6C, 8A)

Material: Two collected slabs containing few specimens. A few additional specimens observed in the field.

\section{Description:}

Hypichnial bilobate, straight or slightly winding ridges, 2.5-8 $\mathrm{mm}$ wide. It displays faint, perpendicular striae in some specimens, while other specimens are smooth.

\section{Remarks:}

The perpendicular striae are most significant morphological features distinguishing this ichnospecies, even if some smooth forms occur in the same population of burrows. Presence of perpendicular striae or smooth surface (like Didymaulichnus isp.) on hypichnia depends on taphonomy. This is well visible in much larger Cruziana furcifera from the study area, where preservation of bioglyphs deteriorates along the bilobate ridge up to their disappearance. Additionally, specimens of $C$. tenella and part of specimens of Cruziana rouaulti (which is generally smooth) are of the same width; indeed, in some cases distinction between these two ichnospecies is problematic.

Cruziana tenella is known from the Cambrian (see Sadlok, 2010 for review), but also from the Grebes Nest Point Formation (Arenigian) of Newfoundland, where it was described under Cruziana stromnessi (Trewin, 1976). Cruziana tenella is commonly described under Isopodichnus, which is a locomotion and feeding trace of phyllopod crustaceans in nonmarine environments (Pollard, 1985). It is widely accepted that Isopodichnus is a junior synonym of Cruziana, though some researches retain this name (e.g., Seilacher, 2007). The taxonomic relation between $C$. tenella and Isopodichnus is problematic (Jensen, 1997). In any case, C. tenella has a priority. It can be referred to the locomotion-feeding activity of small arthropods, including phyllopods for the non-marine variants.

\section{Ichnogenus Didymaulichnus Young, 1972}

Didymaulichnus lyelli (Rouault, 1850) (Fig. 6D)

Material: One slab containing mass occurrence specimens. A few single specimens in the field.

\section{Description:}

Hypichnial, straight to slightly winding, smooth bilobate ridge, 7-10 $\mathrm{mm}$ wide, with a narrow V-shaped median furrow, which is $1 \mathrm{~mm}$ wide. The ridge is bounded by thin, discontinuous bevels, about $1 \mathrm{~mm}$ thick. It occurs together with Cruziana rouaulti in some beds. 

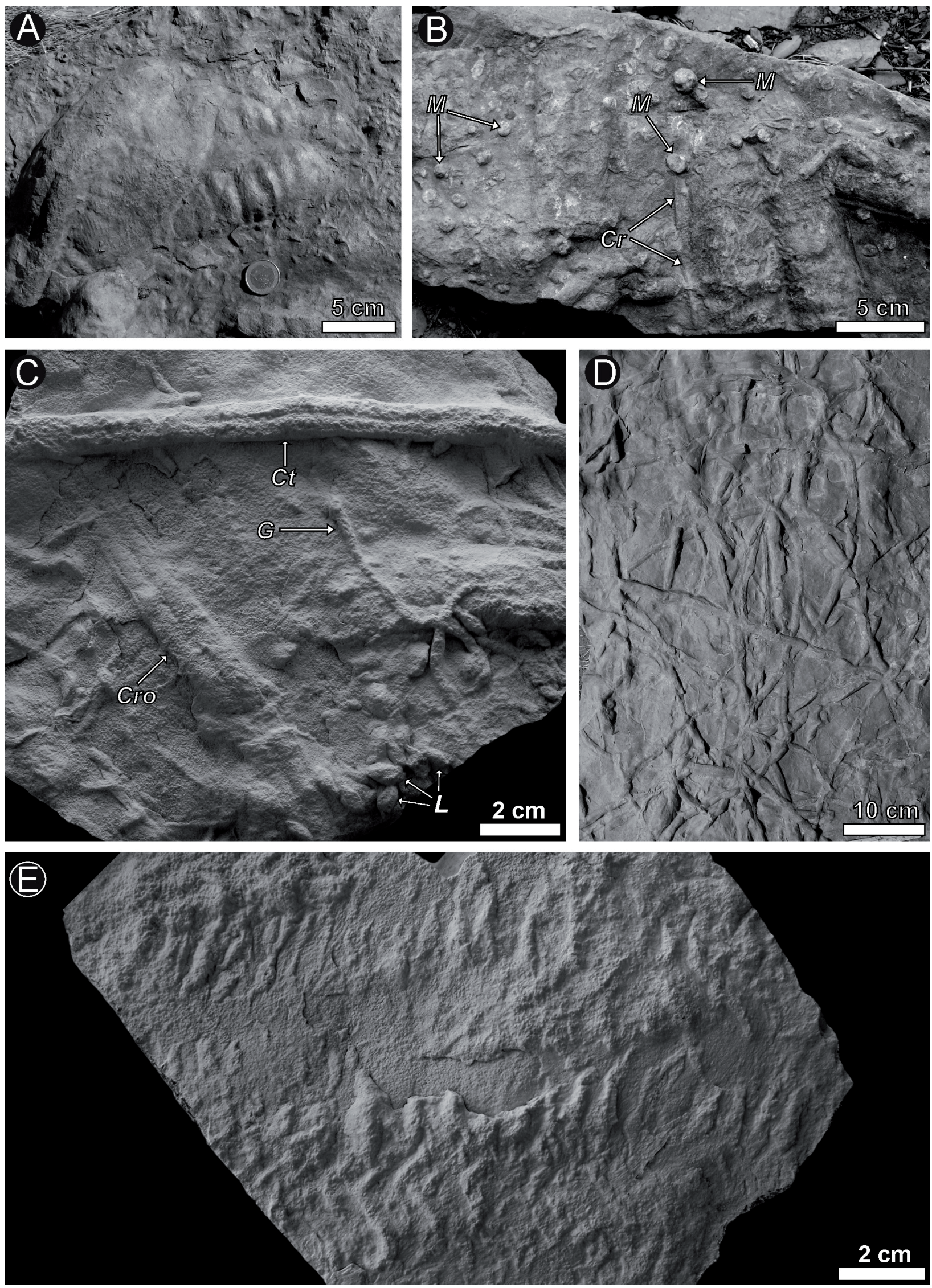

Fig. 6.- A, Cruziana rugosa d’Orbigny, 1842. B, C. rugosa (Cr) and cf. Monocraterion isp. (M). C, Cruziana tenella (Linnarsson, 1871) (Ct), Cruziana rouaulti Lebesconte, 1883 (Cro), Gordia isp. $(G)$ and Lockeia cf. siliquaria James, $1879(L)$. D, Didymaulichnus lyelli Rouault, 1850. E, ?Diplichnites isp. Hypichnial, concave semireliefs on medium beds of sandstone. Cascada de la Cimbarra, Pochico Formation (Lower/Middle Ordovician). 


\section{Remarks:}

Didymaulichnus is interpreted as a trail of gastropods (Glaessner, 1969; Hakes, 1976) or trilobites (Crimes, 1970; Bradshaw, 1981). Didymaulichnus is a common facies-crossing trace fossil in the Lower Palaeozoic (for a review see Fillion and Pickerill, 1990; Kumpulainen et al., 2006). D. lyelli is known from the Armorican Quartzite (Durand, 1985a).

\section{Ichnogenus Diplichnites Dawson, 1873}

?Diplichnites isp. (Fig. 6E)

Material: One specimen collected.

\section{Description:}

The trace fossil is composed of two parallel rows of hypichnial, irregular to more regular ridges, which are arranged obliquely to the main axis of the structure. Each row is 25-30 $\mathrm{mm}$ wide and separated by the median smooth part, about $20 \mathrm{~mm}$ wide. The whole structure is about $60 \mathrm{~mm}$ wide. The rows are composed of mostly straight ridges, which are 1-2 $\mathrm{mm}$ wide, $3-5 \mathrm{~mm}$ apart. Some of them appear to be outwardly bifid, but in others it is not evident due to poor preservation. In one row a wide V-shaped arrangement of the ridges is also present.

Remarks:

A bad state of preservation does not permit closer determination. One can consider it even as an undertrack of Cruziana or Rusophycus, but partial preservation of lower surface of the bed (lower part of Fig. 6E) excludes such a possibility. Diplichnites is interpreted as a locomotion trace of arthropods, typical of Palaeozoic-early Mesozoic shallow-marine, occasionally deeper-marine environments (Fillion and Pickerill, 1990).

\section{Ichnogenus Gordia Emmons, 1844}

Gordia isp. (Fig. 6C)

Material: One collected specimen.

Description:

Convex, hypichnial, subcylindrical ridge forming a loop. The ridge is about $3 \mathrm{~mm}$ wide and loop is about $20 \mathrm{~mm}$ wide. The ridge crosses Didymaulichnus rouaulti.

\section{Remarks:}

Formation of loops is typical of Gordia Emmons, 1844, which is a pascichnion formed by various organisms in different environments (e.g., Fillion and Pickerill, 1990; Geyer and Uchman, 1995). The described form is similar to Gordia marina Emmons, 1844, but fragmentary preservation does not permit a closer determination.

\section{Ichnogenus Lingulichnus Hakes, 1976}

?Lingulichnus verticalis Hakes, 1976 (Fig. 7B)

Material: Two specimens observed on a bedding plane of a loose slab.

\section{Description:}

Elliptical disc on a bedding surface, $15 \mathrm{~mm}$ wide and 22-29 $\mathrm{mm}$ long, with an external bevel riming the disc. The bevel varies in width from 1 to $3 \mathrm{~mm}$.
Remarks:

The discs are a typical bedding plane expression of Lingulichnus, which is a shaft, U-shaped when fully developed, with the elliptical cross-section. The bevel can be an expression of a thick lining. Lingulichnus is interpreted as a domichnion of lingulid brachiopods (Hakes, 1976; Zonneveld and Pemberton, 2003; Zonneveld et al., 2007).

Ichnogenus Lockeia James, 1879

Lockeia cf. siliquaria James, 1879 (Fig. 6C)

Material: Two collected slabs containing several specimens.

\section{Description:}

Lockeia cf. siliquaria occurs as amygdaloidal mounds, which are 3-4 $\mathrm{mm}$ wide and 7-8 $\mathrm{mm}$ long, up to 2-3 $\mathrm{mm}$ high, pointed on both sides, with a median longitudinal keel.

\section{Remarks:}

Stout forms of Lockeia have been ascribed to L. amygdaloides (Seilacher, 1953), and narrow forms to L. siliquaria James, 1879. However, Seilacher and Seilacher (1994) and Schlirf et al. (2001) held them to be morphological variants of $L$. siliquaria James, because they occur in the same beds together with transitional forms between these two ichnospecies. This is the cubichnion produced mostly by bivalves (Seilacher and Seilacher, 1994) in various environments, but mostly shallow-marine settings.

Lockeia isp. (Fig. 7D)

Material: About 30 specimens in a loose slab observed in the field.

Description:

Amygdaloidal or drop-shaped mounds on the lower surface of sandstone beds, which are 16-27 mm wide and 27-60 mm long, pointed on one side (drop-shaped) or both sides.

Remarks:

Its larger size, occasional drop-shape and the absence of a keel are the features differentiating it from Lockeia cf. siliquaria.

\section{Ichnogenus Monocraterion Torell, 1870}

cf. Monocraterion isp. (Figs. 5D, E, 6B, 7A)

Material: Several slabs containing abundant specimens observed in the field.

\section{Description:}

Vertical to subvertical, straight, simple shafts crossing quartzitic sandstone bed, showing a steep conical upper part, filled with mudstone-siltstone. Only a part of the structure limited to the $20 \mathrm{~cm}$ thick host sandstone bed was observed. The conical part is up to $80 \mathrm{~mm}$ long and up to some $10 \mathrm{~mm}$ in diameter in the upper part. In horizontal section, the conical part is manifest on the upper bedding plane as a circular or oval disc-like structure, which is about $10 \mathrm{~mm}$ in diameter, with a centric or eccentric knob of various sizes and occasionally expressed concentric rings. The lower part is expressed on the bedding plane as oval to circular knobs. 

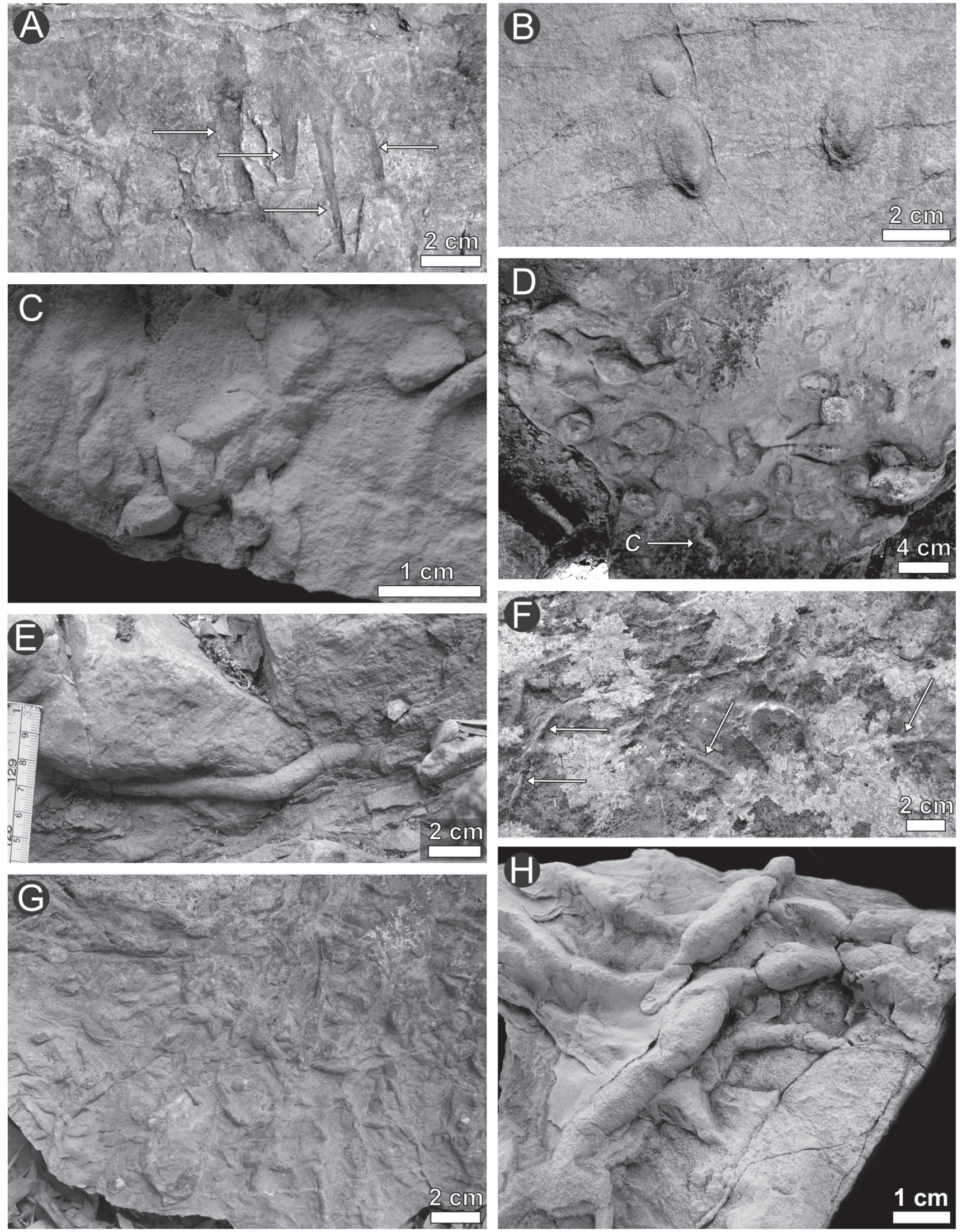

Fig. 7.- A, cf. Monocraterion isp. (arrowed), endichnia, full reliefs in medium bed of sandstone. B, ?Lingulichnus verticalis Hakes, 1976. C, Lockeia cf. siliquaria James, 1879. D, Lockeia isp. and Cochlichnus isp. (C). E, Planolites beverleyensis (Billings, 1862). F, Planolites isp. G, Planolites montanus Richter, 1937. H, Ptychoplasma excelsum Fenton and Fenton, 1937b. B, C, D, F-H, hypichnia, convex semireliefs on thin to medium beds of sandstones; E, endichnion in medium bed of sandstone. Cascada de la Cimbarra, Pochico Formation (Lower/Middle Ordovician). 

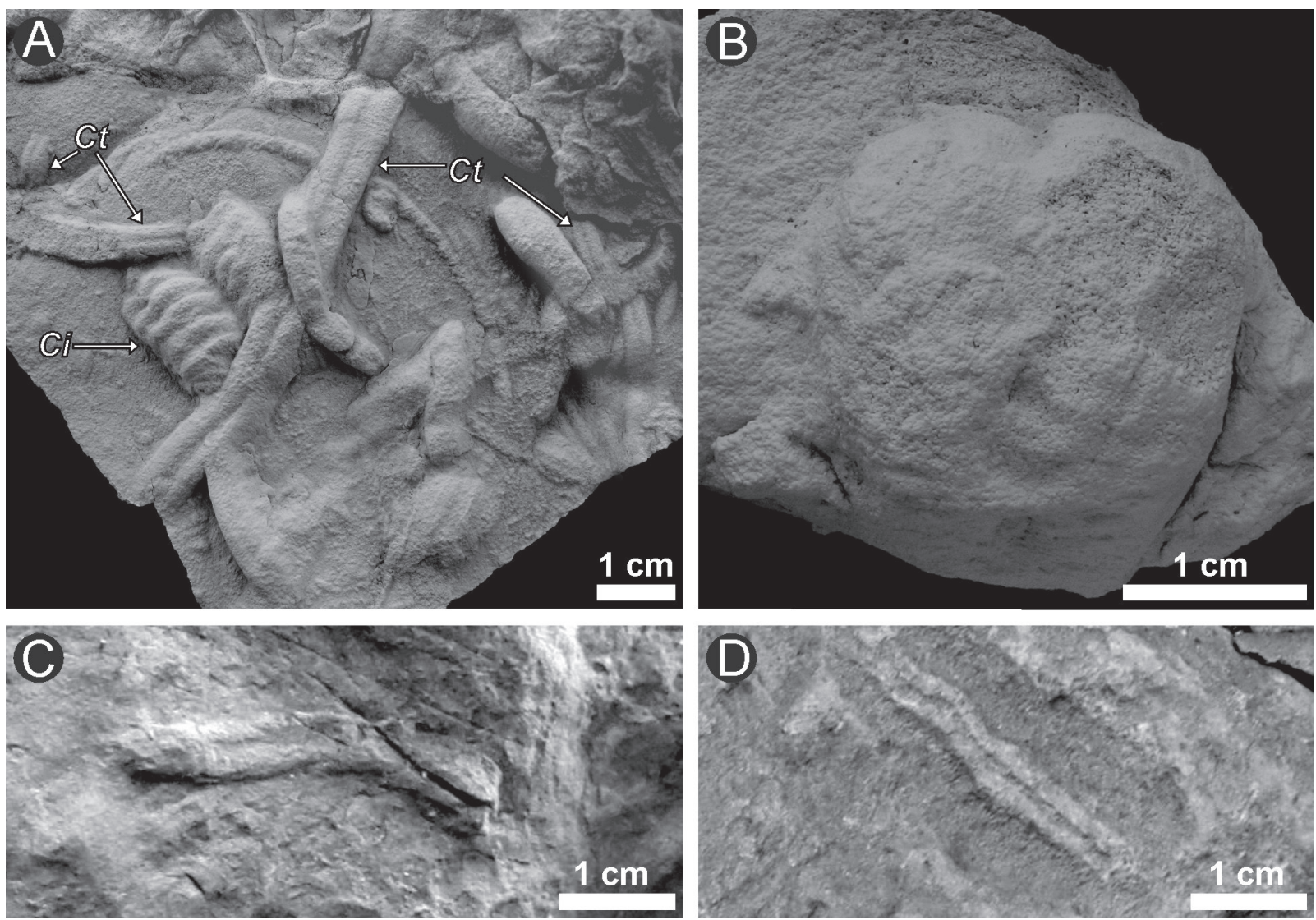

Fig. 8.- A, Cruziana imbricata Seilacher, 1970 (Ci) and Cruziana tenella (Linnarsson, 1871) (Ct); B, Rusophycus isp., hypichnia, convex semireliefs on thin beds of sandstones. C-D, epichnial bilobate ridges on rippled beds. Cascada de la Cimbarra, Pochico Formation (Lower/Middle Ordovician).

\section{Remarks:}

Validity of Monocraterion as a separate ichnogenus, considered by some authors as the same trace fossil as Skolithos Haldeman (interpreted as erosionally truncated Monocraterion) is confirmed (see Fillion and Pickerill, 1990); however, we follow the idea that it is better to separate these with funnel from these without funnel, if the erosional truncation is not evident. The type material displays some ridges running from the funnel, which pose certain unsolved taxonomic problems (Jensen, 1997). Therefore, the described material is determined as cf. Monocraterion isp. Monocraterion sensu lato is typical of shallow-marine, high-energy sandy facies and is interpreted as a domichnion of suspension-feeders or scavengers (e.g., Schlirf and Uchman, 2005).

\section{Ichnogenus Planolites Nicholson, 1873}

Planolites beverleyensis (Billings, 1862) (Fig. 7E)

Material: A few specimens documented in the field.

\section{Description:}

Hypichnial or endichnial, horizontal to oblique, unbranched curved or straight, smooth cylindrical structure, $6-12 \mathrm{~mm}$ in diameter, without distinct lining.

\section{Remarks:}

The diagnosis of $P$. beverleyensis "relatively large, smooth, straight to gently curved or undulate Planolites" (Pemberton and Frey, 1982) fits the described material well. Planolites occurs in various marine and non-marine facies, and is produced by vermiform invertebrates of many phyla, which are interpreted as deposit-feeders that actively fill their burrows (e.g., Pemberton and Frey, 1982; Keighley and Pickerill, 1995).

Planolites montanus Richter, 1937 (Fig. 7G)

Material: A few specimens documented in the field.

Description:

Hypichnial, short, semi-cylindrical, smooth, straight to slightly curved ridges, 6-7 mm wide, up to $23 \mathrm{~mm}$ long. The ridges plunge into the bed.

\section{Remarks:}

This ichnospecies is characterized by common change of orientation on short distances, and what is manifested by short courses on bedding plains, while course of other ichnospecies of Planolites are more stable (Pemberton and Frey, 1982). This trace fossil reflects reworking of mudstone-sandstone interface.

\section{Planolites isp. (Fig. 7F)}

Material: A few specimens documented in the field.

Description:

Planolites isp. is a horizontal to subhorizontal, rarely oblique, unbranched gently curved, rarely straight, smooth cylindrical structure, without distinct lining. There are two dif- 
ferent size classes: the smallest specimens are about $2 \mathrm{~mm}$ in diameter and larger ones about $4 \mathrm{~mm}$ in diameter.

\section{Remarks:}

The mostly horizontal course and the smaller size are the main differences from $P$. beverleyensis, whose diagnosis contains the phrase "relatively large..." (Pemberton and Frey, 1982).

Ichnogenus Ptychoplasma Fenton and Fenton, 1937b

Ptychoplasma excelsum Fenton and Fenton, 1937b (Fig. 7H)

Material: One collected specimen and a few observations in the field.

\section{Description:}

Hypichnial ridges 5-9 mm wide, with elongate, smooth mounds, some of which separated by more even segments. The mounds are amygdaloidal in cross section, 11-20 mm long, up to $9 \mathrm{~mm}$ high and only slightly wider than the even ridge. The overall course is winding; some segments intersect.

\section{Remarks:}

Ptychoplasma excelsum was known so far from the Carboniferous of USA (Fenton and Fenton, 1937b; Rindsberg, 1994). The Arenigian occurrence extends its stratigraphic range. Ptychoplasma is interpreted as the locomotion and feeding trace of bivalves, and occurs in various marine and non-marine environments (Uchman et al., 2011); however, P. excelsum is limited so far to shallow-marine settings (Rindsberg, 1994).

\section{Ichnogenus Rusophycus Hall, 1852}

Remarks:

Rusophycus is a resting trace of arthropods, mostly trilobites in Palaeozoic (Osgood, 1970), considered by Seilacher (1970) as Cruziana, but most authors keep these ichnogenera separate (e.g., Fillion and Pickerill, 1990, for discussion).

\section{Rusophycus isp. (Fig. 8B)}

Material: One collected specimen and a few observations in the field.

\section{Description:}

An oval, bilobate hypichnion, $22 \mathrm{~mm}$ long, $23 \mathrm{~mm}$ wide, 7 $\mathrm{mm}$ high, which consists of two symmetrical lobes separated by an indistinct median furrow. The surface of the lobes is irregular. Incomplete ridges occur on the steep slope of one side. They display a wide V-shaped pattern.

\section{Remarks:}

General shape of the discussed specimen corresponds somewhat with Rusophycus dispar Linnarsson, 1869, although the bad state of preservation does not permit closer determination.

Epichnial bilobate ridge (Fig. 8C-D)

Material: Two specimens in the field.

Description:

Epichnial, smooth, bilobate, slightly curved ridges, with semi-circular lobes that are about $7 \mathrm{~mm}$ wide.
Remarks:

A closer determination is impossible because of fragmentary preservation. Gyrochorte comosa Heer, which is typically preserved as an epichnial bilobate ridge, displays oblique ribbing and is typically narrower (Gibert and Benner, 2002).

\section{Discussion}

\subsection{Palaeoenvironmental aspects}

The trace fossil assemblage is moderately diverse (13 ichnogenera, 19 ichnospecies), dominated by pascichnia ( $\mathrm{Ar}$ chaeonassa, Cruziana, Gordia, Planolites) and repichnia (Cochlichnus, Didymaulichnus, ?Diplichnites, Ptychoplasma), the presence of domichnia (Catenichnus, Lingulichnus, cf. Monocraterion) and cubichnia (Lockeia, Rusophycus). This assemblage is typical of the Cruziana ichnofacies in general (e.g., Frey and Seilacher, 1980) and of the archetypal Cruziana ichnofacies in particular, which in open shelf sediments points to the lower shoreface-upper offshore, where deposit feeding prevails (Pemberton et al., 2001). In the Lower Palaeozoic sediments, a reversal of ichnofacies can occur, i.e., the Cruziana ichnofacies may occur in tidal flat heterolithic sediments, while the Skolithos ichnofacies is present in subtidal sand bars (Buatois and Mángano, 1999, 2004). Nevertheless, there are no signs of tidal environment. Instead, the presence of hummocky cross stratification indicates storm influences, which is consistent with previous observations (Rey and Hidalgo, 2004). The classic facies depth interpretation can therefore be applied. Furthermore, in Portugal, the Armorican Quartzite is interpreted as foreshore-upper offshore sediment (Neto de Carvalho, 2006). This does not necessarily apply to the Armorican Quartzite facies in other regions. For instance, Cruziana-rich facies are referred to tidal flats in NW Spain (Crimes and Marcos, 1976) and in the Armorican Massif (Durand, 1984, 1985a, b; Dabard et al., 2007; Vidal et al., 2011).

The presence of Cruziana, Rusophycus and other trace fossils attributed to trilobites would suggest normal salinity. However, the common occurrence cracks in the upper part of the section (Fig. 3) might be referred to salinity changes, as "syneresis" cracks (Burst, 1965). In this part of the section, the trace fossils are absent. Only in metre 20-21 of the section (Fig. 3) is Cruziana present together with the cracks. However, the latest investigations show that cracks of such type can be intrastratal cracks caused by shrinkage of sediments containing microbial structures (Harzim et al., 2013). Nevertheless, the relation of the cracks to microbial structures is not obvious in the investigated section.

The low degree of sediment reworking suggests a high rate of clastic sedimentation. The most abundant occurrences of trace fossils are in mudstone-sandstone intercalations, where sandstone prevails. Such sediments are probably the most nutritional, attracting deposit feeders, while the preservational potential is high due to lithological heterogeneity, especially on sandstone-mudstone interfaces. Most sandstone beds dis- 
play well preserved primary sedimentary lamination. Not all sandstone-mudstone intercalations contain trace fossils (Fig. 3). Total bioturbation is confined to thin horizons. This may be attributed to a high rate of sedimentation, when the time available for colonization (colonization window sensu Pollard et al., 1993) of bedforms was insufficient.

Generally, trace fossil are relatively uncommon in pure quartzitic sandstones of the Armorican Quartzite facies (e.g., Kolb and Wolf, 1979). Sandstones with some admixture of finer fractions yield characteristic trace fossils, e.g., Skolithos and Daedalus, which are attributable to the Skolithos ichnofacies, indicating a high-energy environment above the fair-weather wave base. The associated heterolithic facies are characterized by abundant pascichnia, such as Cruziana, typical of the Cruziana ichnofacies.

\subsection{Palaeogeographic background}

The Lower Ordovician and Lower/Middle Ordovician trace fossils of the Gondwana and peri-Gondwanan zone are highly diverse. The Ordovician is an important time of biodiversification in shallow marine environments, which is also recorded in trace fossils (Mángano and Droser, 2004). So far, the highest ichnodiversity in the Ordovician (38 ichnogenera) comprises several formations of the Wabana and Bell Island groups in Newfoundland (Fillion and Pickerill, 1990). However, these formations differ from Armorican Quartzite facies formations in that they are composed mostly of shales or heterolithic rocks, except for the Redmans Formation, made up of massive quartzite similar to the Armorican Quartzite. This quartzitic formation yields scarce trace fossils - only Cruziana furcifera was described (Fillion and Pickerill, 1990).

The distribution of some Lower Ordovician trace fossils is controlled by different aspects, among others by palaeogeographical location. Foremost, these concerns trace fossils, which morphology depends largely from anatomy of tracemaker, such as Cruziana or Rusophycus. The Cruziana rugosa group is very common in the Iberian Peninsula, France, Wales, North Africa, southern Asia and South America, which represents the northern margin of Gondwana (e.g., Cocks and Torsvik, 2002). This group of trace fossils is generally absent in Laurentia (continental part of North America and Greenland) and Baltica (Eastern Europe and Scandinavia) (Seilacher and Crimes, 1969). Nevertheless, the palaeogeographical restriction is not strict. The C. rugosa group and other trace fossils, e.g., Trichophycus venosus, were reported from the Norwegian part of Baltica (Knaust, 2004) despite the fact that Baltica during the Ordovician was separated from Gondwana by the Tornquist Sea (e.g., Cocks and Torsvik, 2002).

Mixed Gondwanan-Baltic assemblages of trilobites, which are Cruziana trace-makers, have also been reported from the Cambrian of Poland (Żylińska, 2002). The possibility of preOrdovician paths of migration of ichnofaunas between Laurentia and Baltica palaeocontinents, based on Rusophycus, was mentioned by Stachacz (2012).
In other hand, the distribution of trace fossils in the Ordovician is also facies controlled (Mángano and Droser, 2004). Baltica, which during the Ordovician was closer to the Equator, is characterized by dominant condensed carbonate sedimentation, with numerous discontinuity surfaces (Cocks and Torsvik, 2005). The Baltica facies are rich in skeletal fossils and relatively scarce in trace fossils (Ekdale and Bromley, 2001, 2003; Dronov et al., 2002; Dronov and Mikuláš, 2010), especially Cruziana, which is believed to be a palaeo-ichnozoogeographic marker. One can invoke an effect of antagonism between suspension feeders and deposit feeders, i.e. trophic group amensalism (Rhoads and Young, 1970), which is also applicable to trace fossils (Bromley, 1996; Buatois and Mángano, 2011). It is an open question if the tropic group amensalism, observed generally in a scale of habitat, can be extrapolated to whole continents. Probably, the stronger role was played by the taphonomic filter, as preservation of trilobite trace fossils is highest in heterolithic siltstone-sandstone deposits (Crimes, 1975; Goldring, 1985). The calcareous, commonly condensed sediments of Baltica are not suitable for preservation of trilobite burrows.

\section{Conclusions}

The described trace fossils belong to the archetypal Cruziana ichnofacies, indicating a lower shoreface-upper offshore zone. A high rate of sedimentation limited the colonization window of bedforms, causing a generally low degree of bioturbation.

The studied trace fossil assemblage has significant but not strict palaeogeographic implications in the Gondwana and peri-Gondwanan context. The trace fossil assemblages of Cruziana ichnofacies in the Armorican Quartzite facies (margins of Gondwana) are characterized by common large Cruziana, in this sense differing from the Baltica setting. Ichnofauna of Early Ordovician was palaeogeographically controlled, although trilobite related ichnotaxa typical of Gondwana can be found rarely in Baltica and Laurentia. The differences between the ichnofauna of Gondwana and Baltica may be influenced by the facies (clastics in Gondwana and carbonates in Baltica), mostly owing to the preservation potential of Cruziana, which is high in heterolithic clastic sediments.

\section{Acknowledgements}

The paper benefited from comments and suggestions by Drs Gutiérrez-Marco (Instituto de Geociencias; CSIC, UCM) and one Anonymous Reviewer. A. U. and M. S. received additional support from Jagiellonian University. Research by R.-T. was supported by Projects CGL2008-03007, and CGL2012-33281 (Secretaría de Estado de I+D+I, Spain), Project RNM-3715 and Research Group RNM-178 (Junta de Andalucía). The previous version of the paper benefitted from critical review of Nicholas Minter (Portsmouth, UK). 


\section{References}

Aceñolaza, G.F., Milana, J.P. (2005): Remarkable Cruziana beds in the Lower Ordovician of the Cordillera Oriental, NW Argentina. Ameghiniana 42, 633-637.

Baldwin, C.T. (1975): The stratigraphy of the Cabos Series in the section between Cadavedo and Laurca, Province of Oviedo, N. W. Spain. Breviora Geológica Astúrica 19, 4-9.

Baldwin, C.T. (1977a): Rusophycus morgati: An asaphid produced trace fossil from the Cambro-Ordovician of Brittany and northwest Spain. Journal of Paleontology 51, 411-425. http://www.jstor.org/stable/ i 255830

Baldwin, C.T. (1977b): Internal structures of trilobite trace fossils indicative of an open surface furrow origin. Palaeogeography, Palaeoclimatology, Palaeoecology 21, 273-284. doi: 10.1016/00310182(77)90039-6

Baldwin, C.T. (1977c): The stratigraphy and facies associations of trace fossils in some Cambrian and Ordovician rocks of north western Spain. In: Crimes, T.P., Harper, J.C. (eds.), Trace fossils 2, Geological Journal, Special Issue 9, 9-40.

Bergström, J., Peel, J.S. (1988): Lower Cambrian trace fossils from northern Greenland. Rapport Grønlands geologisk Undersøgelse 137, 43-53.

Bergström, S.M., Chen, X., Gutiérrez-Marco, J.C., Dronov, A.V. (2009): The new chronostratigraphic classification of the Ordovician System and its relations to major regional series and stages and $\delta^{13} \mathrm{C}$ chemostratigraphy. Lethaia 42, 97-107. doi: 10.1111/j.15023931.2008.00136.x

Billings, E. (1862): New species of fossils from different parts of the Lower, Middle and Upper Silurian rocks of Canada. In: Palaeozoic Fossils, Volume I (1861-1865). Geological Survey of Canada, Dawson Brothers, Montreal, 96-168.

Bouyx, E. (1966): Répartition verticale des pistes bilobées dans l'Ordovicien inférieur de la provincie Ciudad Real (Espagne méridional). Compte Rendu Sommaire des séances de la Société géologique de France 1966 (1), 88-89.

Bradshaw, M. (1981): Paleoenvironmental interpretations and systematic of Devonian trace fossils from the Taylor Group (Lower Beacon Supergroup), Antarctica. New Zealand Journal of Geology and Geophysics 24, 615-652. doi:10.1080/00288306.1981.10421537

Bromley, R.G. (1996): Trace Fossils. Biology, Taphonomy and Applications. Second Edition. Chapman and Hall, London, 361 p.

Buatois, L.A., Mángano, M.G. (1999): Ichnofacies models in Early Paleozoic tide-dominated quartzites: onshore-offshore gradients and the classic Seilacherian paradigm. Acta Universitatis Carolinae 43, 151-154.

Buatois, L.A., Mángano, M.G. (2004): Terminal Proterozoic-Early Cambrian ecosystems: ichnology of the Puncoviscana Formation, northwest Argentina. In: Webby, B.D., Mángano, M.G., Buatois L.A. (eds), Trace Fossils in Evolutionary Palaeoecology, ed. Fossils and Strata 51, 1-16.

Buatois, L.A., Mángano, M.G. (2011): Ichnology: Organisms-Substrate Interactions in Space and Time. Cambridge University Press, Cambridge, $358 \mathrm{p}$.

Buckman, J.O. (1994): Archaeonassa Fenton and Fenton 1937 reviewed. Ichnos 3, 185-192. doi:10.1080/10420949409386387

Burst, J.F. (1965): Subaqueously formed shrinkage cracks in clay. Journal of Sedimentary Research 35, 348-353.

Butenweg, P. (1968): Geologische Untersuchungen im Ostteil der Sierra Morena nordöstlich von La Carolina (Prov. Jaén, Spanien). Münstersche Forschungen zur Geologie und Paläontologie 6, 126 p.

Cocks, L.R.M., Torsvik, T.H. (2002): Earth geography from 500 to 400 million years ago: a faunal and palaeomagnetic review. Journal of the Geological Society, London 159, 631-644. doi: 10.1144/0016764901-118
Cocks, L.R.M., Torsvik, T.H. (2005): Baltica from the late Precambrian to mid-Palaeozoic times: The gain and loss of a terrane's identity. EarthScience Reviews 72, 39-66. doi:10.1016/j.earscirev.2005.04.001

Crimes, T.P. (1970): Trilobite tracks and other trace fossils from the Upper Cambrian of North Wales. Geological Journal 7, 47-68. doi: 10.1002/gj.3350070104

Crimes, T.P. (1975): The production and preservation of trilobite resting and furrowing traces. Lethaia 8, 35-48. doi: 10.1111/j.15023931.1975.tb00914.x

Crimes, T.P., Marcos, A. (1976): Trilobite traces and the age of the lowest part of the Ordovician reference section for NW Spain. Geological Magazine 113, 349-356. http://dx.doi.org/10.1017/ S0016756800047622

Dabard, M.P., Loi, A., Paris, F. (2007): Relationship between phosphogenesis and sequence architecture: Sequence stratigraphy and biostratigraphy in the Middle Ordovician of the Armorican Massif (NW France). Palaeogeography, Palaeoclimatology, Palaeoecology 248, 339-356. doi: 10.1016/j.palaeo.2006.12.011

d’Orbigny, A. (1842): Voyage dans l'Amérique méridionale (le Brésil, la République orientale de l'Uruguay, la République Argentine, la Patagonie, la République du Chili, la République de Bolivia, la République du Pérou) exécuté pedant les années 1826, 1827, 1829, 1830, 1831, 1832 et 1833, pt. 4 (Paléontologie). Pitois-Levrault (Paris), Levrault (Strasbourg).

Dawson, J.W. (1873): Impressions of footprints of aquatic animals and imitative markings, on Carboniferous rocks. American Journal of Science 5, 16-24.

Delgado, J.F.N. (1886a): Terrains palézoiques du Portugal. Étude sur les Bilobites et autres fossiles des quartzites de la base du système Silurique du Portugal. Académie Royale des Sciences, Lisbonne.

Delgado, J.F.N. (1886b): Étude sur les Bilobites et autres fossiles des quarzites de la base du système Silurique du Portugal. Sections des Travaux Géologiques de Portugal, Académie Royale des Sciences, Lisbonne.

Dronov, A., Mikuláš, R. (2010): Paleozoic Ichnology of St. Petersburg region. IV Workshop on Ichnotaxonomy. Excursion Guidebook. Russian Academy of Science, Moscow. Transactions of the Geological Institute 596, 1-70.

Dronov, A.V., Mikuláš, R., Logvinova, M. (2002): Trace fossils and ichnofabrics across the Volkhov depositional sequence (Ordovician, Arenigian of St. Petersburg Region, Russia). Journal of the Czech Geological Society 47, 133-144.

Durand, J. (1984): Ichnocenoses du grès Armoricain (Ordovicien Inférieur du Massif Armoricain) dans leur contexte sédimentologique. Geobios, Memoir Special 8, 189-197. DOI : 10.1016/S00166995(84)80172-2

Durand, J. (1985a): Les traces fossiles paleobiologices de milieux: un exemple dans l'Ordivicien Armoricain. Bulletin du Muséum national d'histoire naturelle. Section C, Sciences de la terre, paléontologie, géologie, minéralogie $\mathrm{C} 3,215-227$.

Durand, J. (1985b): Les Grès Armoricain. Sédimentologie-Traces fossiles. Milieux de dépôt. Mémoires et Documents, Centre Armoricain d'Etude Structurale des Socles, 3, 1-150.

Egenhoff, S.O., Weber, B. Lehnert, O., Maletz, J. (2007): Biostratigraphic precision of the Cruziana rugosa group: a study from the Ordovician succession of southern and central Bolivia. Geological Magazine 144, 289-303. doi: 10.1017/S0016756807003093

Ekdale, A.A., Bromley, R.G. (2001): Bioerosional innovation for living in carbonate hardgrounds in the Early Ordovician of Sweden. Lethaia 34, 1-12. doi: 10.1080/002411601300068152

Ekdale, A.A., Bromley, R.G. (2003): Paleoethologic interpretation of complex Thalassinoides in shallow-marine limestones, Lower Ordovician, southern Sweden. Palaeogeography, Palaeoclimatology, Palaeoecology 192, 221-227. doi: 10.1016/S0031-0182(02)00686-7 
Emig, C.C., Gutierrez Marco, J.C. (1997): Signification des Niveaux à lingulidés à la limite supérieure du Grès Armoricain (Ordovician, Arenig, SW Europe). Geobios 30, 481-495. doi: 10.1016/S00166995(97)80116-7

Emmons, E. (1844): The Taconic System: Based on observations in NewYork, Massachusetts, Maine, Vermont, and Rhode-Island. Caroll and Cook, Albany, 67 p.

Fenton, C.L., Fenton, M.A. (1937a): Archaeonassa: Cambrian snail trails and burrows. American Midland Naturalist 18, 454-458.

Fenton, C.L., Fenton, M.A. (1937b): Burrows and trails from Pennsylvanian rocks of Texas. American Midland Naturalist 18, 1079-1084.

Fillion, D., Pickerill, R.K. (1990): Ichnology of the Upper Cambrian? to Lower Ordovician Bell Island and Wabana groups of Eastern Newfoundland, Canada. Palaeontographica Canadiana 7, 1-83.

Fortey, R.A., Owens, R.M. (1999): Feeding habits in trilobites. Palaeontology 42, 429-465. doi: 10.1111/1475-4983.00080

Frey, R.W., Seilacher, A. (1980): Uniformity in marine invertebrate ichnology. Lethaia 13, 183-207. doi: 10.1111/j.1502-3931.1980.tb00632.x

Geyer, G., Uchman, A. (1995): Ichnofossil assemblages from the Nama Group (Neoproterozoic-Lower Cambrian) in Namibia and the Proterozoic-Cambrian boundary problem revisited. Beringeria Special Issue 2, 175-202.

Gibert, J.M. de, Benner, J.S. (2002): The trace fossil Gyrochorte: ethology and paleoecology. Revista Española de Paleontología 17(1), 1-12.

Glaessner, M.F. (1969): Trace fossils from the Precambrian and basal Cambrian. Lethaia 2, 369-393. doi: 10.1111/j.1502-3931.1969. tb01258.x

Głuszek, A. (1995): Invertebrate trace fossils in the continental deposits of an Upper Carboniferous coal-bearing succession, Upper Silesia, Poland. Studia Geologica Polonica 108, 171-202.

Goldring, R. (1985): The formation of the trace fossil Cruziana. Geological Magazine 122, 65-72. doi: 10.1017/S0016756800034099

Gutiérrez-Alonso, G., Fernández-Suárez, J., Gutiérrez-Marco, J.C., Corfu, F., Murphy, J.B., Suárez, M. (2007): U-Pb depositional age for the upper Barrios Formation (Armorican quartzite facies) in the Cantabrian zone of Iberia: Implications for stratigraphic correlation and paleogeography. In: Linnemann, U., Nance, R.D., Kraft, P., Zulauf, G. (eds.), The evolution of the Rheic Ocean; from Avalonian-Cadomian active margin to Alleghenian-Variscan collision. Geological Society of America, Special Papers 423, 287-296.

Gutiérrez-Marco, J.C., Robardet, M., Rábano, I., Sarmiento, G.N., Lancha, M.Á.S.J., Araújo, P.H., Pindal. A.P.P. (2002): Ordovician. In: Gibbons, W., Moreno, T. (eds.), Geology of Spain. The Geological Society, Bath, 31-49.

Gutiérrez-Marco, J.C., Abréu Sá, A., Capdevila García-Bellido, D., Rábano, I. (2013). The extent of the Middle Ordovician Stage in peri-Gondwanan Europe and north Africa: stratigraphic record, biostratigraphic tools and regional chronostratigraphy. GFF, 2013, doi: 10.1080/11035897.2013.865667

Hakes, W.G. (1976): Trace fossils and depositional environment of four clastic units, Upper Pennsylvanian megacyclothems, northeast Kansas. The University of Kansas, Paleontological Contributions 63, $1-46$.

Hall, J. (1852): Palaeontology of New-York. II. Containing Descriptions of the Organic Remains of the Lower Middle division of the New-York System (Equivalent in Part to the Middle Silurian rock of Europe). Geological Survey of New York, C. Van Benthuysen, Albany, New York, $362 \mathrm{p}$.

Harazim, D., Callow, R.H.T., Mcllroy, D. (2013): Microbial mats implicated in the generation of intrastratal shrinkage ('syneresis') cracks. Sedimentology 60, 1621-1638. doi: 10.1111/sed.12044

Hitchcock, E. (1858): Ichnology of New England: A Report on the Sandstone of the Connecticut Valley, Especially its Fossil Footmarks. Natural Sciences of America Reprint, Boston, 220 p.
Hofmann, H.J., Patel, I.M. (1989): Trace fossils from the type „Etchemian Series" (Lower Cambrian Ratcliffe Brook Formation), Saint John area, New Brunswick, Canada. Geological Magazine 126, 139157. doi: $10.1017 / \mathrm{S} 0016756800006294$

Hofmann, R., Goudemand, N., Wasmer, M., Bucher, H., Hautmann, M. (2011): New trace fossil evidence for an early recovery signal in the aftermath of the end-Permian mass extinction. Palaeogeography, Palaeoclimatology, Palaeoecology 310, 216-226. doi: 10.1016/j.palaeo.2011.07.014

James, U.P. (1879): Description of new species of fossils and remarks on some others, from the Lower and Upper Silurian rocks of Ohio. The Paleontologist 3, 17-24.

Jensen, S. (1997): Trace fossils from the Lower Cambrian Mickwitzia sandstone, south-central Sweden. Fossils and Strata 42, 1-110.

Julivert, N., Fontboté, J.M., Ribeiro, A., Conde, L.E. (1972): Mapa tectónico de la Península Ibérica y Baleares, 1:1.000.000, Memoria Explicativa, Instituto Geológico y Minero de España.

Keighley, D.G., Pickerill, R.K. (1995): The ichnotaxa Palaeophycus and Planolites: historical perspectives and recommendations. Ichnos 3, 301-309. doi:10.1080/10420949509386400

Knaust, D. (2004): Cambro-Ordovician trace fossils from the SW-Norwegian Caledonides.Geological Journal 39, 1-24. doi: 10.1002/gj.941

Kolb, S., Wolf, R. (1979): Distribution of Cruziana in the Lower Ordovician sequence of Celtiberia (NE Spain) with a revision of the Cruziana rugosa-group. Neues Jahrbuch für Geologie und Paläontologie Monatshefte 1979, 457-474.

Kumpulainen, R.A., Uchman, A., Woldehaimanot, B., Kreuser, T., Ghirmay, S. (2006): Trace fossil evidence from the Adigrat Sandstone for an Ordovician glaciation in Eritrea, NE Africa. Journal of African Earth Sciences 45, 408-420. doi: 10.1016/j.jafrearsci.2006.03.011

Lebesconte, M. (1883): Présentation des oeuvres posthumes de Marie Roualt, suivie d'une note sur les Cruziana et Rusophycus. Bulletin de la Société géologique de France sér. 3, XI, 466-472.

Lebesconte, M. (1886): Constitution générale du massif breton comparée à celle du Finistére. Bulletin Société Géologique de France sér. $3,14,776-811$.

Lillo, F.J., López-Sopeña, F., Pieren, A., Hernández-Samaniego, A., Salazar, A., Gutiérrez-Marco, J.C., Sarmiento, G.N., Pardo-Alonso. M.V., in press: Mapa y memoria explicativa de la hoja 863 (Aldeaquemada) del Mapa Geológico 1:50.000. Instituto Geológico y Minero de España.

Linnarsson, J.G.O. (1869): On some fossils found in the Eophyton sandstones at Lugnås in Sweden. Geological Magazine 6, 393-406.

Linnarsson, J.G.O. (1871): Geognostiska och palaeontologiska iakttagelser öfver Eophytonsandstenen i Vestergötland. Kongliga Svenska Vetenscaps. Akademiens Handlingar 9, 1-19.

Mángano, M.G., Buatois, L.A. (2003): Trace fossils. In: Benedetto, J.L. (Ed.), Ordovician Fossils of Argentina. Universidad Nacional de Córdoba, Secretaría de Ciencia y Tecnología, 507-553.

Mángano, M.G., Droser, M. (2004): The ichnologic record of the Ordovician radiation. In: Webby, B.D., Droser, M.L., Paris, F., Percival, I.G. The Great Ordovician Biodiversification Event. Columbia University Press, New York, 369-379.

Matas-González, J., Leyva, F., Cabra, P., Granados, L.F., GutiérrezMarco, J.C., Rodríguez-González R.M. (2009): Mapa y memoria explicativa de la hoja 864 (Venta de los Santos) del Mapa Geológico 1:50.000. Instituto Geológico y Minero de España.

McCarthy, B. (1979): Trace fossils from a Permian shoreface - foreshore environment, Eastern Australia. Journal of Paleontology 53, 345-366. http://www.jstor.org/stable/1303876

Neto de Carvalho, C. (2006): Roller coaster behavior in the Cruziana rugosa group from Penha Garcia (Portugal): Implications for the feeding program of trilobites. Ichnos 13, 255-265. doi: $10.1080 / 10420940600843740$ 
Nicholson, H.A. (1873): Contributions to the study of the errant annelids of the older Palaeozoic rocks. Proceedings of the Royal Society London 21, 288-290.

Osgood, R.G., Jr. (1970): Trace fossils of the Cincinnati area. Palaeontographica Americana 6, 281-444.

Pemberton, G.S., Frey, R.W. (1982): Trace fossil nomenclature and the Planolites - Palaeophycus dilemma. Journal of Paleontology 56, 843-881. http://www.jstor.org/stable/1304706

Pemberton, G.S., Spila, M., Pulham, A.J., Saunders, T., MacEachern, J.A., Robbins, D., Sinclai, I.K. (2001): Ichnology \& Sedimentology of shallow to marginal marine systems: Ben Nevis \& Avalon Reservoirs, Jeanne D'Arc Basin. Geological Association of Canada, Short Course Notes 15, $343 \mathrm{p}$.

Pérez Regodón, J. (1966): Nota sobre yacimientos fósiles encontrados en Sierra Morena. Notas y Comunicaciones del Instituto Geológico y Minero de España 91, 7-12.

Pickerill, R., Romano, M., Meléndez, B. (1984): Arenig trace fossils from the Salamanca area, western Spain. Geological Journal 19, 249269. doi: $10.1002 /$ gj. 3350190305

Pollard, J.E. (1985): Isopodichnus, related arthropod trace fossils and notostracans from Triassic fluvial sediment. Transactions of the Royal Society of Edinburgh, Earth Sciences 76, 273-285. doi: http://dx.doi. org/10.1017/S026359330001049X

Pollard, J.E., Goldring, R., Buck. S.G. (1993): Ichnofabrics containing Ophiomorpha: significance in shallow-water facies interpretation. Journal of the Geological Society of London 150, 149-164. doi: 10.1144/gsjgs.150.1.0149

Poupon, G. (1971): Contribution a l'étude de la région d'Aldeaquemada (Jaén, Espagne). Msc. Thesis, Université Paris-Sud (Orsay): 60 p.

Rey, J., Hidalgo, M.C. (2004): Siliciclastic sedimentation and sequence stratigraphic evolution on a storm-dominated shelf: the Lower Ordovician of the Central Iberian Zone (NE Jaén, Spain). Sedimentary Geology 164, 89-104. doi: 10.1016/j.sedgeo.2003.08.004

Rhoads, D.C., Young, D.K. (1970): The influence of deposit feeding organisms on sediment stability and community trophic structure. Journal of Marine Research 28, 150-178.

Richter, R. (1937): Marken und Spuren aus allen Zeiten. I-II. Senckenbergiana 19, 150-169.

Rindsberg, A.K. (1994): Ichnology of the Upper Mississippian Hartselle Sandstone of Alabama, with notes on other Carboniferous formations. Geological Survey of Alabama, Bulletin 158, 1-107.

Romano, M. (1991): Lower to middle Ordovician trace fossils from the Central Iberian Zone of Portugal and Spain. In: C.R. Barnes, S.H Williams (eds.), Advances in Ordovician geology, ed. Geological Survey of Canada 90-9, 191-204.

Rouault, M. (1850): Note préliminaire sur une nouvelle formation découverte dans la terrain silurien inférieur de la Bretagne. Bulletin de la Société Géologique de France, série 2, 7, 724-744.

Sá, A.A., Gutiérrez-Marco, J.C., Piçarra, J.M., García-Bellido, D.C., Vaz, N., Aceñolaza, G.F. (2011): Ordovician vs. «Cambrian» ichnofossils in the Armorican Quartzite of Central Portugal. In: GutiérrezMarco, J.C., Rábano, I., García-Bellido, D. (eds.), Ordovician of the World, Cuadernos del Museo Geominero 14, 483-492.

Sadlok, G. (2010): Trace fossil Cruziana tenella from the Furongian (Upper Cambrian) deposits of Poland. Acta Geologica Polonica 60 (3), 349-355.

Schlirf, M., Uchman, A. (2005): Revision of the ichnogenus Sabellarifex Richter, 1921 and its relationship to Skolithos Haldeman, 1840 and Polykladichnus Fürsich, 1981. Journal of Systematic Palaeontology 3(2), 115-131. doi: 10.1017/S1477201905001550

Schlirf, M., Uchman, A., Kümmel, M. (2001): Upper Triassic (Keuper) non-marine trace fossils from the Haßberge area (Franconia south-eastern Germany). Paläontologische Zeitschrift 75, 71-96. doi: 10.1007/BF03022599
Seilacher, A. (1953): Studien zur Palichnologie II. Die fossilen Ruhespuren (Cubichnia). Neues Jahrbuch für Geologie und Paläontologie, Abhandlungen 98, 87-124.

Seilacher, A. (1970): Cruziana stratigraphy of "non-fossiliferous" Palaeozoic sandstones. In Trace Fossils, ed. Crimes, T.P., and J.C. Harper. Geological Journal, Special Issue 3, 447-476.

Seilacher, A. (2007): Trace Fossil Analysis. Springer, Heidelberg, 226 p. Seilacher, A., Crimes, T.P. (1969): „European” species of trilobite burrows in eastern Newfoundland. American Association of Petroleum Geologists, Memoir 12, 145-148.

Seilacher, A., Seilacher, E. (1994): Bivalvian trace fossils: a lesson from actuopaleontology. Courier Forschung Senckenberg 169, 5-15.

Stachacz, M. (2012): New finds of Rusophycus from the lower Cambrian Ociesęki Sandstone Formation (Holy Cross Mountains, Poland). Geological Quarterly 56, 237-248. doi: 10.7306/gq.1018

Stanley, T.M., Feldmann, R.M. (1998): Significance of nearshore tracefossil assemblages of the Cambro-Ordovician Deadwood Formation and Aladdin Sandstone, South Dakota. Annals of Carnegie Museum 67(1), 1-51.

Tamain, G. (1972): Recherches géologiques et minières en Sierra Morena orientale (Espagne). PhD. Thesis, Université Paris-Sud (Orsay). Travaux du Laboratoire de Géologie Structurale et Appliquée 91, 1, 369 p.

Torell, O. (1870): Petrificata Suecana Formationis Cambricae. Lunds Universitet Arsskrift 6, 2, 1-14.

Torsvik, T.H., Cocks, L.R.M. (2011): The Palaeozoic palaeogeography of central Gondwana. In: D.J.J. Van Hinsbergen, S.J.H. Buiter, T.H. Torsvik, C. Gaina, S.J. Webb. (eds.), The Formation and Evolution of Africa: A Synopsis of 3.8 Ga of Earth History, Geological Society London Special Publications 357, 137-166.

Trewin, N.H. (1976): Isopodichnus in a trace fossil assemblage from the Old Red Sandstone. Lethaia 9, 27-39. doi: 10.1111/j.1502-3931.1976. tb00947.x

Uchman, A., Mikuláš, R., Rindsberg. A.K. (2011): Mollusc trace fossils Ptychoplasma Fenton and Fenton, 1937 and Oravaichnium Plička and Uhrová, 1990: their type material and ichnospecies. Geobios 44, $387-$ 397. doi: 10.1016/j.geobios.2010.08.001

Vidal, M., Loi, A., Dabard, M.P., Botquelen, A. (2011): A Palaeozoic open shelf benthic assemblage in a protected marine environment. Palaeogeography, Palaeoclimatology, Palaeoecology 306, 27-40. doi: 10.1016/j.palaeo.2011.03.025

Von Raumer, J.F., Stampfi, G.M., Bussy, F. (2003): Gondwana-derived microcontinents: the constituents of the Variscan and Alpine collisional orogens. Tectonophysics 365, 7-22. doi: http://dx.doi.org/10.1016/ S0040-1951(03)00015-5

Yochelson, E.L., Fedonkin, M.A. (1997): The type specimens (Middle Cambrian) of the trace fossil Archaeonassa Fenton and Fenton. Canadian Journal of Earth Sciences 34, 1210-1219. doi: 10.1139/e17-097

Young, F.G. (1972): Early Cambrian and older trace fossils from the southern Cordillera of Canada. Canadian Journal of Earth Sciences 9, 1-17. doi: 10.1139/e72-001

Zonneveld, J.P., Pemberton, S.G. (2003): Ichnotaxonomy and behavioral implications of lingulide-derived trace fossils from the Lower and Middle Triassic of Western Canada. Ichnos 10, 25-39. doi: 10.1080/10420940390238249

Zonneveld, J.P., Beatty, T.W., Pemberton S.G. (2007): Lingulide brachiopods and the trace fossil Lingulichnus from the Triassic of western Canada: Implications for faunal recovery after the end-Permian mass extinction. Palaios 22, 74-97. doi: 10.2110/palo.2005.p05-103r

Żylińska, A. (2002): Stratigraphic and biogeographic significance of Late Cambrian trilobites from Łysogóry (Holy Cross Mountains, central Poland). Acta Geologica Polonica 52, 217-238. 